\title{
明治期におりる \\ 中国小説字典についてに
}

鳥 居 久 靖

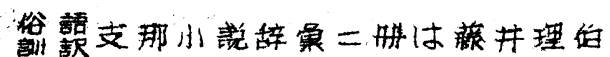

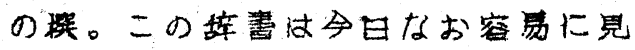
探るところのものであるか的しい 紹介の要はないであろう。

以下なるべく要をつまへで考を 聥めたい。

本兽の発刊中明治43年(1910) 2月25日である加，編者の矵言は 紀元 2538 第) 2 月(1878)

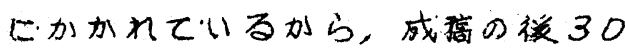
年にして発刊を見たわけミ゙ある。二 030进という求い成月何によ子 加。二れを竑明する通磪な料をも

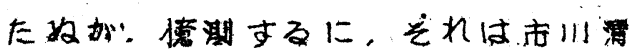

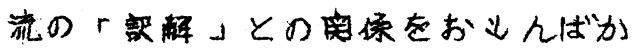
つてのニとではなかろっか。前逃の

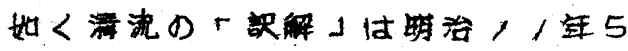
月晒免竍，との年の10月20日 には早くも刻成されている。二れは

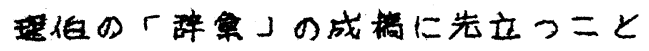
琒かに2ム月である。後这するよう

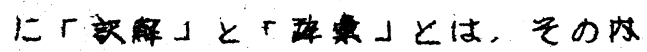
客江て大国である加ら，伯は「

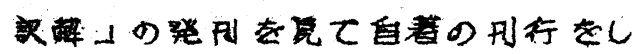

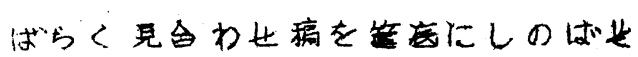
ざるを得なくなった。をして「訳解」 加やや稀観となる顷おい无て，二 和を上样した。しかむ加とんで自家

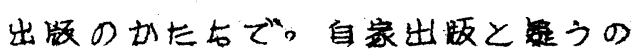

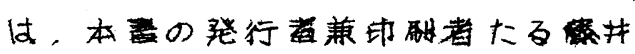
利八と伯とは同一人ではないかと いう坡制加らである。この推测は， 理伯と山う号(おそらくは号)は， 科人といわ名の者に意して称した しのとの筆者の想像わらである利，

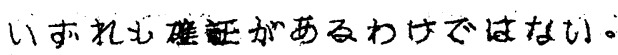

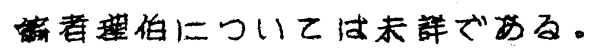
例言に「舌耕の余暖」という言免加 あるところから推して，あるいは熟 か等校の敏师などを在たるなりわい としていたのではないかと㜖像する だけである。

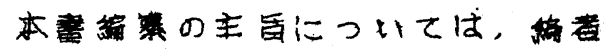
が例言でニれ套明的かにている。

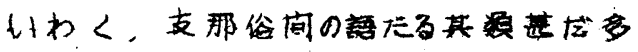

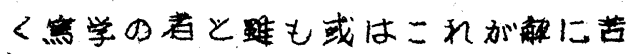

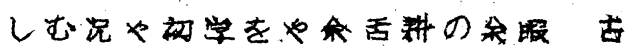

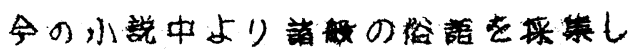




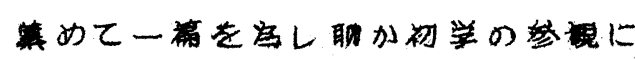

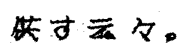

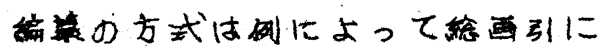

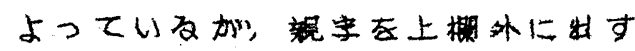

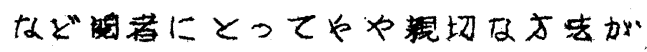
譪价られているが医の数え方にや

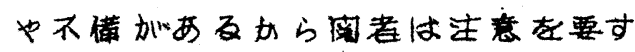
る。たとえ机叫を㗅に作って七画に

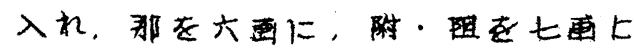
雨孝大禹仁しっとも索引ぞは西に 作って六雷江入れる)，成を同心く 六西に入れるなど。全語最に漠音衣 附すこど，短語には剖点を施すこと など、「訳解」と軌を一にする。

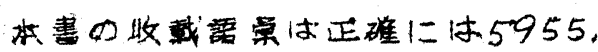
ます6000と見て大過はない。十 视解」に哥了こと的3000，广安 林」に沈や劣るが，語䣋肉かなり部 継でありここ点では「字林」にまさる こと数である。

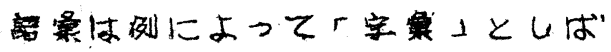
しば互胃するが，光の模涉は，「字 林」とはいささか灰異仁する。と いうのは本喤の語は。「字象上よ

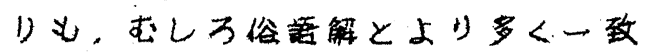
するからである。今本害の「ー上の

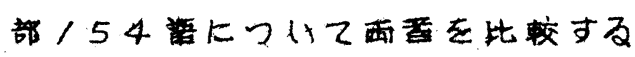

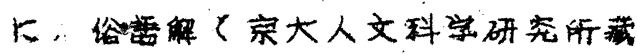

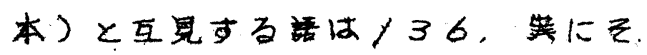
の88\%胎に当る。下不」の部㓅 てみれば。「辞果」の数ワ/のつ

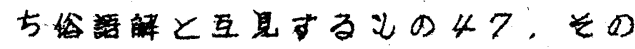

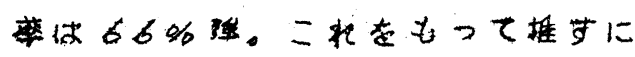

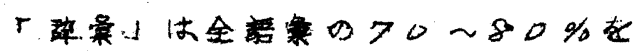

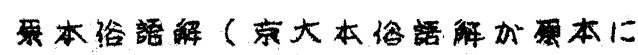
比較的近いものであるこ己は，さき にも触たうに蚶いで成つた出のと 吉える。

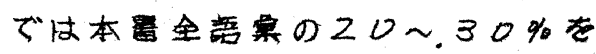

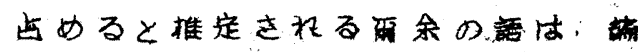

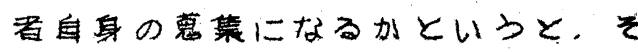
うではない。前記「一」の成

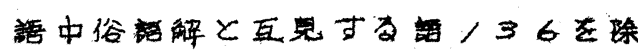

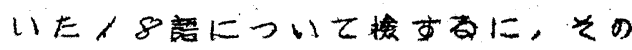

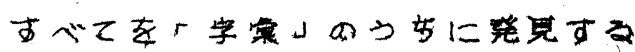

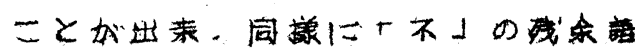

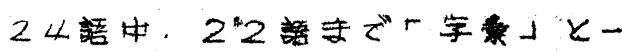

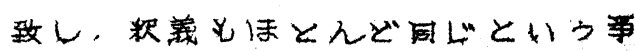

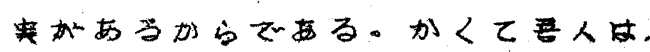

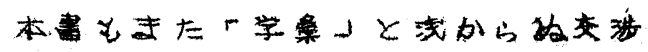
を持っすとを定世さるを得ないの である。では「辟事」の褊者は。俗

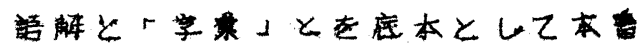

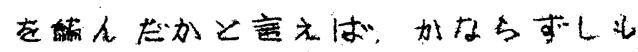
そつとは断じ加たい。なぜな执は， 「部解山の例に二見る上小に，「字

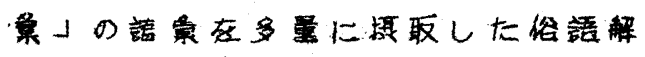
の别本加在した二と必充分予想 权るからである。染者は，端者理伯 は，清流め「政解」に於けると同じ く、自家のした俗解くかならず しシ一本のみではなったか加知的

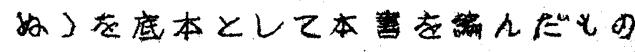

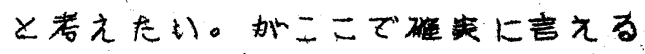
ことは，理伯の扰った浴語解テクス 卜は：清流の费れより，なり多量上 「字菜」の要採り入れたものであ つたろう、ということである。 
(230)

かくてわれわれは，「辞魚」は俗 語解の燌㨁し本であることを雄め得 た。统者加例空にいう「余舌耕の余 㗇古今わ小説中より諸般の俗語を採 集し算めて一萹となし云々」は，お 取下げを願わでるを得ない仕儀とな OE。

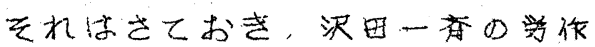

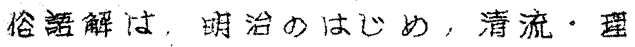

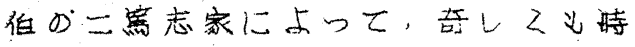
を同心゙りして世影彰されんとした のでめつて，先捙の坊は清流の占め るところとなったが、加，年ののち 再度二れ在世に䁌うた理伯の功必沼

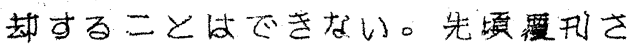

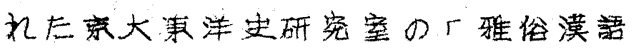
訳解」を併世れば。一斉の功は，明 治加ら昭和に加たり，三度び世の学 者を真することになったわけでめり， 地下の一网心定加满足しているこ とであるう。

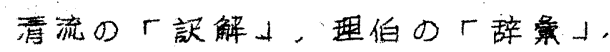
ともに俗語解を底本として編まれた 二と，前述牞如くであるが，では两 者口度容壮同一汃と言うと，加なら ずしもそうではない。たとえば「一 」の部について声えば,「辞戴」に

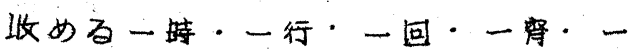

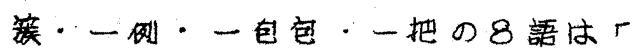
訳解」には見えず「「不」では「辞 路」の不当・不毒不秃・不了不当・ 不留心・不管好多。不看得破・不草 不乘・不接而回! 不秀文・不像意他 一不順言・不知端的, 不知怎的・不
值得・不長不短・不上不下・不客・

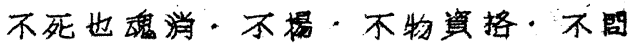
天地・不韵の22語は「訳解」には

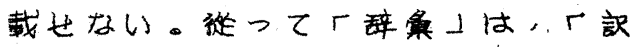
解」にプラスするものなにがしか はあるわけである。しかし「不」の 不当、不毒不秃以下の洒は，すべて 「字稪」に見られるのであって、こ 好より可れは”，「訳解」と「字龟」

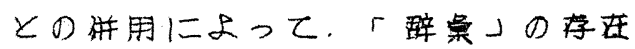
価傮のほとんどは失われることにな る。まったくと言わすほとんどと控 之目に言ったのは，「一」部の一行

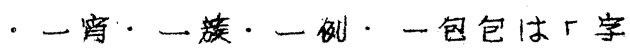
棠」にも見えず，票本俗語解にの文 胃られるものであり，二うしたもの は「辞賞」全畫を通すれば。まだね にがしかは揄出できるはずだからで ある。加，乏の数は限られたもので

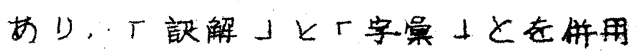
すれは”。辞算」を参する要はま すないといつ前言に大逼はないと 橫柰及。

次に绤解の再生に対して編者力 とった態度にっきー言しさろ。

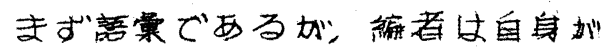
蔵したであろう俗語解の全語条をそ のまま採ったのではなく，編者自身 の好みによりかなりの取括汃行われ ている。それは纷解的推定落条み

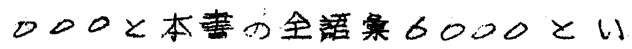
う数の上からの比船でも直らにうな ずかれるところであり，その具体的 数字はさきに行したとおりである。 
この際、編者加りかなる万料のもと に取唅したかについては明らかでな い。

次に歌域の態。編百はだいたい に於て䛦語解の光れを。そのまま移 すを建前としている加，次の著しい

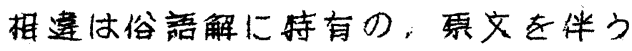
出典や先人の群細右考証は全部削つ てしまい，その要たけを摘記した

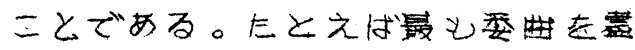
したと言われる「稓道」の她き，本 書では，ナニトシテ。イカンド。ナ ニトテカタアルベキヤ・イカンシテ。 イカデ力。難道不成小心，イカンゾ サヤウ二、ナルベキャト云フ7。此 ノ二字二八訓梳頗儿多シ（下63お）

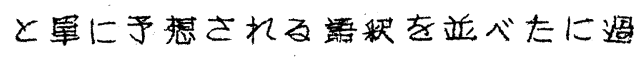
ぎ好。これは突用を王にした編者の 當四に出るものであるうが、合日か

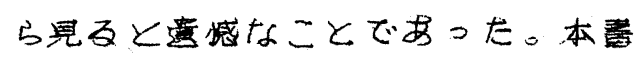
の利用価值は，その将載语数の少な いことをしばらく度外梘するとして

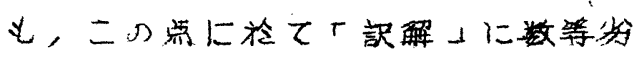
万。

时士一去兒(一丢兒) 一一睡(一 侓つの如き魯魚の誤りもないではな いが、机して校散は行き启いており。

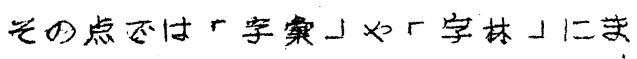
さること方々だる。

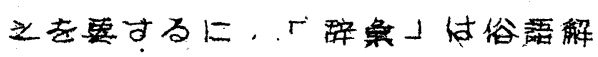

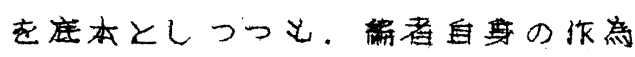
が多分に期えられており，俗語解衣

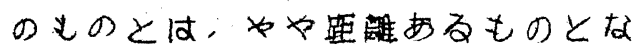
つた。并の点，㭲語解上出来得る限

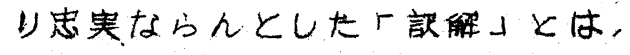
效度を異にする。このことについて の評每は，本辧を利用する人によっ

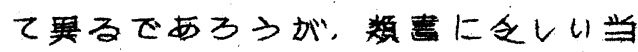
時(今口でもあるわけではない代) としては，世の学者を益したこと是 いなく，䦂者の労を不当におとしめ てはならはい。省乙筆者は，本墨の 战立を分析すること，西まりに舤遠 兔に週ざたようであるが、兰水はこ

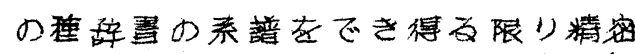
に探ろうとする意目加らであって他 意あるわけではない。加の石山福治 氏の大著最新支那語大辞典加，本琶 に大星の䇉を和いていることも，本

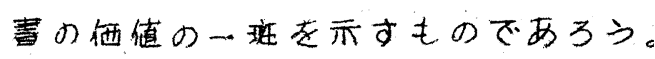

結語

本稿およð゙前稿「秋水橉主人小説 字棠区め心゙って」(天理大学学荤： 等」6輯つによって、「字棠」を中 心として、小説用語堂披った辞琹の いくつ加上つき，它の雅を探つて 来た加，之を要するに，江户の中期 加的明治上加けて上样された水説字

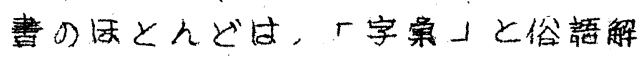
にの多くを仰いで成った方のだあ 儿，辞㻎編寒者た5の態度はやや安 易に通さたと言えよう。しかしなが ら俗語解り如き。气の道に志寸人士 によって当然利用さるべくして利用 され得皮加った名著を校訂彯刻して一

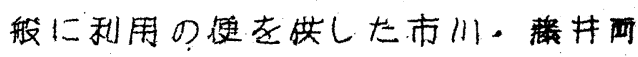
氏力功清は小さいものではない。「 


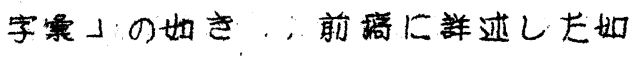

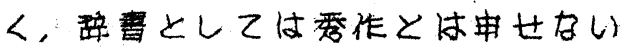
牛のだはある加，今日なおとの利时

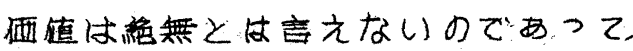
これを自著に利用した先人の態度も

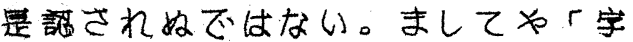
慗」以外に類毒に乏し加った等时と しては问更である。

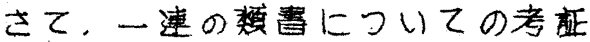

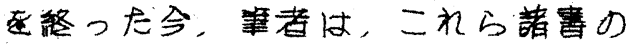
現代的洒犆を決定すべき段取りとな

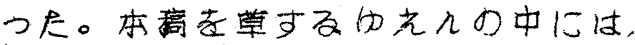
これら諸害の現代的価値を評定しは

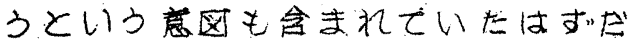
加らである。が本稿は一応こ二で淘 釷したい。それは叙上によっても諸 㻎の併值はほほ判定されるはずであ り，また具体的な資料を提供世す”し て，役に立つと加，立た奴と加結 することは，得てして個人の主観加 入り易い加らである。筆者过目下こ れら一連の辞鲞の語魚を集大成した 厂近世中国語語案」と包名づく心゙き 一書を編むべく㺺楮をすすめており， その全を明かし得る日もさして 遠くないと信する。ての功を䋲える ことによって無用の言を㪦す要记少 くなるてめろうし，また評定の辢を 轨るとしても，時期として之の万が 遍当であろる。(終)
前 号 勘 誤 (主なる。ののか）

\begin{tabular}{|c|c|c|}
\hline 真行 & 讙 & 正 \\
\hline $\begin{array}{l}2 \pi 4 \\
=24\end{array}$ & $\begin{array}{l}\text { 不敬 } \\
\text { ○站 }\end{array}$ & $\begin{array}{l}\text { 不吱 } \\
\text { 厂䚿解」 }\end{array}$ \\
\hline . 33 & $\begin{array}{l}53 \text { 語中…‥の次下 } \\
\text { 次の語を入れる。 }\end{array}$ & 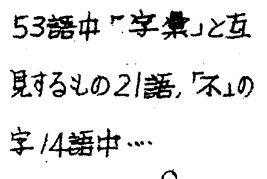 \\
\hline 35 & $\begin{array}{l}\text { 吃了伦淨变 } \\
00000\end{array}$ & 吃了怄淨光 \\
\hline $\begin{array}{l}16 \pm 2 \\
"=24\end{array}$ & 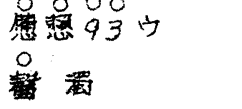 & 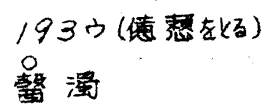 \\
\hline 16 元 2 & 助嘅 & 眨喑 \\
\hline$\Rightarrow 5$ & 播 $147 \%$ & \\
\hline$\because 19$ & 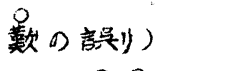 & 款 \\
\hline 17 右 2 & 幕末の競案前に & 营末の增 筑劧に \\
\hline
\end{tabular}

※なお丁のオモテを示す片汃なのオが しはしば戈になっているから訂正あり たい。 